\title{
ACKNOWLEDGEMENTS
}

Thanks to:

All of the contributors (as authors, researchers and interviewees) to individual national studies contained in this volume.

All our friends at the Institute of Communications Studies, University of Leeds, who saw us through all the stages of this project, in particular Stephen Hay, Simon Popple, John Edmonds, Isobel Rich, Cristina Archetti, Myria Georgiou, Vibha Metha and Robin Brown.

Everybody at EUP - and in particular Sarah Edwards for uncomplaining responses to requests for 'just a little more time . . . something really interesting has come up...'

John Orr for his ongoing interest in this project.

\section{Dorota Ostrowska -}

I would like to thank my parents, Irena and Jan Ostrowscy, and my brother, Wojciech, who have always been there for me, following the progress on the book and supporting me in their own unique ways. I would like to thank the Louis Le Prince Centre for the financial support, which allowed me to conduct interviews in Denmark and undertake research in Paris and in Warsaw.

I would like to thank Stephen Hay for helping us to arrange a range of interviews in France, which proved to be invaluable for the completion of this book.

I would like to make special thanks to Søren Falgaard who was helping me with researching the Danish chapter. I also would like to thank the staff of the Danish Film Institute, Filmoteka Narodowa and Archiwum Telewizji Polskiej TVP SA in Warsaw.

I would like to thank Heather Wallis for stimulating discussions about filmmaking and scriptwriting, for her ongoing support and care, and for opening widely the doors of her home and welcoming me so generously on so many occasions. I would like to thank Charlotte and Sammy who grew up together with the project for just being there and most of all I would like to thank Graham for giving me a chance to work on this book with him, for taking my hand and leading me through all the stages of the process. He was holding me when I was falling.

Graham Roberts -

All of the above of course - minus myself and adding Dorota Ostrowska who 
has the invaluable knack of letting you think you are helping her when it is invariably t'other way round. I have received moral and intellectual support from a number of colleagues at Leeds and beyond including Lucia Nagib, Paul Cooke, Graeme Harper, Rob Stone and Owen Evans. I would also like to publicly express my thanks to friends, neighbours and family (including Shirley Roberts, all the Days and the good people of the Back Lane) - you have no idea how much I need you to keep on keeping on. Most of all to Heather Wallis good enough a friend to tell me when I may not be getting it quite right. 